\title{
Lithuanian energy security level assessment based on indicator dependence
}

\author{
J. Augutis ${ }^{1,2}$, R. Krikštolaitis ${ }^{1,2}$ \& S. Pečiulyte ${ }^{1}$ \\ ${ }^{1}$ Vytautas Magnus University, Lithuania \\ ${ }^{2}$ Lithuanian Energy Institute, Lithuania
}

\begin{abstract}
The issue of energy security has recently become especially important and problematic in Lithuania. Prior to 2010, Lithuania was a nuclear power energy producing country; however the second (last) unit of Ignalina NPP was shutdown at the end of 2009. Thus, Lithuania is currently producing a part of electricity in its thermal power plants and imports the other part. The purpose of this paper is to assess Lithuanian energy security level taking into account various security indicators whose values were obtained from statistical data. The indicator system was divided into three blocks, namely: technical, economical and socio-political, and each block was divided into groups. As the indicators, ascribed to groups, are interdependent, these dependencies were invoked for the calculation of the weights of indicators. Additionally, the paper presents pilot calculations and the comparison of energy security level in Lithuania in 2007, 2010 and after the construction of a liquefied natural gas terminal.
\end{abstract}

Keywords: energy security level assessment, security level, energy security indicators.

\section{Introduction}

Although security of energy supply has always been an important field of national security in every country, it has recently gained even greater attention in the policy agenda due to the growing dependence of industrialized economies on energy consumption and the increased frequency of supply disruption. Energy security is a vast field encompassing such areas as mining, conversion and transportation of primary energy sources, generation, distribution and supply of 
energy, functioning of infrastructure, secure life of society in technical, economical, socio-political and environmental point of view.

Energy security conception is understood differently. Finding rational solutions for energy supply security requires evaluating the costs and probability of supply disruptions, comparing the present energy supply security level with the forecasts, and deciding on the strategies for its improvement. Different approaches are used for assessing security of energy supply, such as: geopolitical assessment of scenarios, economical modelling, expert risk assessment, analysis of primary energy sources, and development of security indicators system. The presented research is based on the latter indicator system for the assessment of Lithuanian energy security level.

Sufficient security level of energy supply is vital to the functioning of modern economy since reliable supply is necessary to ensure industrial activities and satisfy population needs. A secure energy supply is one of the priorities of country's energy sectors because it is an integral part of national security [1]. This issue receives a great deal of attention from the European Union (EU); and is a strategic task of the North Atlantic Treaty Organization (NATO) aiming at a stable power supply to the members of the alliance.

The issue of energy security has recently become especially important and problematic in Lithuania. Prior to 2010, Lithuania was a nuclear power energy producing country; however, the second (last) unit of Ignalina NPP was shutdown in the end of 2009. Thus, Lithuania is currently producing a part of electricity in its thermal power plants and imports the other part. According to the Lithuanian National Energy (Energy Independence) Strategy [2], a liquefied natural gas (LNG) terminal and electricity network between Lithuania and Sweden NORDBALT are going to be built.

The main reasons for the construction of the LNG terminal are the following [2]:

- diversification of natural gas supply and freedom from the dependence on a single gas supplier;

- $\quad$ provision of emergency natural gas reserve enabling Lithuania to cover the emergency demand for gas independently;

- $\quad$ gaining access to gas spot markets;

- fulfilling the preconditions for forming a primary gas market in Lithuania.

Thus, the purpose of the paper is to assess Lithuanian energy security level taking into account various security indicators. The calculations and comparison of energy security level in Lithuania in 2007, in 2010 and after the construction of LNG terminal are also presented.

\section{Energy security indicators system}

The calculation of energy security level is based on security indicators which are special indexes giving numerical values to important issues in energy sector security. 
Material for indicator systems can be received from statistical data, economical modelling, reliability modelling, experts' judgment and social/political assessment, which is often based on hypothetical probabilities received from lognormal distribution.

Assessing the energy security level of Lithuania, at first the indicator blocks and groups were constructed and their weights determined. Three indicator blocks were created, namely: technical block, economic block and socio-political block. Equal weights were attributed to all three blocks: $s_{i}=1 / 3, i=1,2,3$, assuming that they have equal impact on the level of energy security.

The groups of technical and economic blocks were distinguished according to the kind of fuel used in the energy system. Electricity and heat were additionally included in the composition of these indicator blocks as separate groups of indicators. The technical and economic blocks, the weights of indicator groups $s_{i j}, i=1,2, j=1, \ldots, m$ were identified considering each kind of fuel and electricity, as well as heat consumption and calculating the part of relative oil fuel equivalents by thousands of tons in the total energy consumption. These group weights change depending on the modelling scenario, whereas the weights of groups in the socio-political block were determined as equal: $s_{31}=s_{32}=1 / 2$.

When presenting the indicators of the technical block, technical and reliability parameters were taken into account, emphasizing the capacity of fuel supply to Lithuania, annual or maximum demands, energy generators lifetime and accumulated fuel reserves.

During the formation of the indicators of economic block, most attention was paid to the annual demand for appropriate kind of fuel, a possibility to choose fuel suppliers freely, diversification of fuel suppliers, and the ratio of the imported fuel to annual consumption.

The socio-political block was divided into two groups: geopolitical indicators and socio-political indicators. The aim of the former is to assess the internationally announced political ratings of the state and foreign countries, the energy resources are supplied from and through by transit. The values of these indicators were taken from International Country Risk Guide [3]. The aim of socio-political indicators is to present the implementation of the assumed international obligations and EU directives in Lithuania and to describe the ratio of energy consumption to gross domestic product.

All indicators are presented in table 1 by giving their titles and factual values $X_{i j k}$, where $i=1, \ldots, \mathrm{n}-$ block number, $j=1, \ldots, \mathrm{m}$ - group number in the block, $k=1, \ldots, 1-$ indicator number in the group, threshold pre-critical $\left(\right.$ pctv $\left._{i j k}\right)$ and critical $\left(c t v_{i j k}\right)$ state values [4]. All indicators are given in percents.

\section{The algorithm of energy security level assessment}

In order to identify the level of security of energy supply, the state of each indicator should be evaluated. For this purpose, the pre-critical $p c t v_{i j k}$ and critical $c t v_{i j k}$ threshold values of indicators were determined by experts. Then, the indicators were evaluated in points using an evaluation scale constructed for each indicator (see fig. 1). The direction of indicator values was considered in creation 
Table 1: $\quad$ Indicators for energy security level assessment.

\begin{tabular}{|c|c|c|c|}
\hline $\mathrm{Nr}$ & Name of the indicator & Notation & $\begin{array}{c}\text { Direction } \\
\text { of the } \\
\text { scale }\end{array}$ \\
\hline 1 & Technical block & & \\
\hline 1.1 & Electricity & & \\
\hline 1.1 .1 & $\begin{array}{l}\text { Ratio of total installed power capacity of generators } \\
\text { and connection lines to the maximal power demand }\end{array}$ & $X_{111}$ & $\max$ \\
\hline 1.1 .2 & $\begin{array}{l}\text { Ratio of the largest power plant capacity to installed } \\
\text { capacity of the whole system }\end{array}$ & $X_{112}$ & $\min$ \\
\hline 1.1 .3 & $\begin{array}{l}\text { The maximal share of a single installed technology in } \\
\text { the total production of electricity }\end{array}$ & $X_{113}$ & $\min$ \\
\hline 1.1 .4 & $\begin{array}{l}\text { Average ratio of power units lifetime to their technical } \\
\text { resource time }\end{array}$ & $X_{114}$ & $\max$ \\
\hline 1.2 & Gas & & \\
\hline 1.2 .1 & $\begin{array}{l}\text { Ratio of total pipeline capacity to maximum gas } \\
\text { consumption }\end{array}$ & $X_{121}$ & $\max$ \\
\hline 1.2 .2 & $\begin{array}{l}\text { Ratio of gas amount possible to store in gas storages to } \\
\text { average annual consumption }\end{array}$ & $X_{122}$ & $\max$ \\
\hline 1.2 .3 & $\begin{array}{l}\text { Ratio of the capacity of the largest gas supply facility } \\
\text { to average consumption }\end{array}$ & $X_{123}$ & $\min$ \\
\hline 1.3 & Oil & & \\
\hline 1.3 .1 & $\begin{array}{l}\text { Ratio of the potential supply of oil and its products to } \\
\text { Lithuania to average annual consumption }\end{array}$ & $X_{131}$ & $\max$ \\
\hline 1.3 .2 & $\begin{array}{l}\text { Ratio of the capacity of the largest supplier of oil and } \\
\text { its products to annual consumption }\end{array}$ & $X_{132}$ & $\min$ \\
\hline 1.3 .3 & $\begin{array}{l}\text { Ratio of accumulated reserves of oil products to } \\
\text { average annual consumption }\end{array}$ & $X_{133}$ & $\max$ \\
\hline 1.4 & Coal & & \\
\hline 1.4 .1 & $\begin{array}{l}\text { Ratio of technical capacities of coal supply to annual } \\
\text { demand }\end{array}$ & $X_{141}$ & $\max$ \\
\hline 1.4 .2 & $\begin{array}{l}\text { Ratio of the capacity of the largest coal supplier to } \\
\text { annual coal demand }\end{array}$ & $X_{142}$ & $\min$ \\
\hline 1.4 .3 & $\begin{array}{l}\text { Ratio of accumulated reserve of coal to average annual } \\
\text { consumption }\end{array}$ & $X_{143}$ & $\max$ \\
\hline 1.5 & Nuclear fuel & & \\
\hline 1.5 .1 & $\begin{array}{l}\text { Ratio of technical possibilities of nuclear fuel supply } \\
\text { to annual demand }\end{array}$ & $X_{151}$ & $\max$ \\
\hline 1.5 .2 & $\begin{array}{l}\text { Ratio of spent nuclear fuel repository capacity to } \\
\text { demand (during assessment) }\end{array}$ & $X_{152}$ & $\max$ \\
\hline 1.5 .3 & $\begin{array}{l}\text { Ratio of the accumulated nuclear fuel amount to } \\
\text { average annual consumption }\end{array}$ & $X_{153}$ & $\max$ \\
\hline 1.6 & Biofuel & & \\
\hline 1.6 .1 & $\begin{array}{l}\text { Ratio of biofuel production capacity to annual } \\
\text { consumption of biofuel }\end{array}$ & $X_{161}$ & $\max$ \\
\hline
\end{tabular}


Table 1: $\quad$ Continued.

\begin{tabular}{|c|c|c|c|}
\hline $\mathrm{Nr}$ & Name of the indicator & Notation & \begin{tabular}{|c|} 
Direction \\
of the \\
scale
\end{tabular} \\
\hline 1.6 .2 & $\begin{array}{l}\text { Ratio of the capacity of the largest biofuel producer to } \\
\text { annual consumption }\end{array}$ & $X_{162}$ & $\min$ \\
\hline 1.6 .3 & $\begin{array}{l}\text { Ratio of accumulated biofuel reserve to average annual } \\
\text { consumption }\end{array}$ & $X_{163}$ & $\max$ \\
\hline 1.7 & \multicolumn{3}{|l|}{ Heat } \\
\hline 1.7 .1 & $\begin{array}{l}\text { Ratio of the total capacity of the installed heat } \\
\text { generators to maximal heat demand }\end{array}$ & $X_{171}$ & $\max$ \\
\hline 1.7 .2 & $\begin{array}{l}\text { Average ratio of average lifetime of power units to } \\
\text { their technical resource time }\end{array}$ & $X_{172}$ & $\max$ \\
\hline 1.7 .3 & $\begin{array}{l}\text { Share of one heat production technology generating } \\
\text { the most heat in the total heat production }\end{array}$ & $X_{173}$ & $\min$ \\
\hline 1.7 .4 & $\begin{array}{l}\text { Percentage of heat production which can be replaced } \\
\text { by another kind of fuel without changing technology }\end{array}$ & $X_{174}$ & $\max$ \\
\hline 2 & \multicolumn{3}{|l|}{ Economical block } \\
\hline 2.1 & \multicolumn{3}{|l|}{ Electricity } \\
\hline 2.1 .1 & $\begin{array}{l}\text { Ratio of the amount of electricity purchased in the } \\
\text { electricity market to average annual demand for } \\
\text { electricity }\end{array}$ & $X_{211}$ & $\max$ \\
\hline 2.1 .2 & $\begin{array}{l}\text { Ratio of the average cost of electricity (for } 1 \mathrm{kWh} \text { ) to } \\
\text { open market average cost }\end{array}$ & $X_{212}$ & $\min$ \\
\hline 2.1 .3 & $\begin{array}{l}\text { Share of consumers who freely choose the producer of } \\
\text { electricity }\end{array}$ & $X_{213}$ & $\max$ \\
\hline 2.1 .4 & $\begin{array}{l}\text { Ratio of the amount of electricity which can be } \\
\text { produced using fuel imported only from one supplier } \\
\text { to the total amount of produced electricity }\end{array}$ & $X_{214}$ & $\min$ \\
\hline 2.1 .5 & $\begin{array}{l}\text { Ratio of the imported electricity amount to annual } \\
\text { demand for electricity }\end{array}$ & $X_{215}$ & $\min$ \\
\hline 2.2 & \multicolumn{3}{|l|}{ Gas } \\
\hline 2.2 .1 & $\begin{array}{l}\text { Ratio of gas amount purchased in the gas market to } \\
\text { average annual gas consumption }\end{array}$ & $X_{221}$ & $\max$ \\
\hline 2.2 .2 & $\begin{array}{l}\text { Ratio of the purchase cost of } 1000 \text { cubic meters of gas } \\
\text { to the average gas purchase cost in the EU countries }\end{array}$ & $X_{222}$ & $\min$ \\
\hline 2.2 .3 & Possibility for consumers to choose a gas supplier & $X_{223}$ & $\max$ \\
\hline 2.2 .4 & $\begin{array}{l}\text { Share of the imported gas from a single possible } \\
\text { supplier }\end{array}$ & $X_{224}$ & $\min$ \\
\hline 2.2 .5 & $\begin{array}{l}\text { Ratio of the amount of imported gas to average annual } \\
\text { gas consumption }\end{array}$ & $X_{225}$ & $\min$ \\
\hline 2.3 & \multicolumn{3}{|l|}{ Oil } \\
\hline 2.3 .1 & $\begin{array}{l}\text { Ratio of the amount of oil purchased in the oil market } \\
\text { to average annual oil consumption }\end{array}$ & $X_{231}$ & $\max$ \\
\hline 2.3 .2 & Possibility for consumers to choose an oil supplier & $X_{232}$ & $\max$ \\
\hline
\end{tabular}


Table 1: $\quad$ Continued.

\begin{tabular}{|c|c|c|c|}
\hline $\mathrm{Nr}$ & Name of the indicator & Notation & \begin{tabular}{|c|} 
Direction \\
of the \\
scale
\end{tabular} \\
\hline 2.3 .3 & $\begin{array}{l}\text { Ratio of the purchase cost of oil and its products to } \\
\text { average open market cost }\end{array}$ & $X_{233}$ & $\min$ \\
\hline 2.3 .4 & Share of the imported oil from a single supplier & $X_{234}$ & $\min$ \\
\hline 2.3 .5 & $\begin{array}{l}\text { Ratio of the amount of imported oil to average annual } \\
\text { oil consumption }\end{array}$ & $X_{235}$ & $\min$ \\
\hline 2.4 & \multicolumn{3}{|l|}{ Coal } \\
\hline 2.4 .1 & $\begin{array}{l}\text { Ratio of the amount of coal purchased on coal market } \\
\text { to average annual consumption }\end{array}$ & $X_{241}$ & $\max$ \\
\hline 2.4 .2 & Possibility for consumers to choose a coal supplier & $X_{242}$ & $\max$ \\
\hline 2.4 .3 & $\begin{array}{l}\text { Ratio of the purchase cost of coal to average open } \\
\text { market cost }\end{array}$ & $X_{243}$ & $\min$ \\
\hline 2.4 .4 & $\begin{array}{l}\text { Share of the imported coal from a single possible } \\
\text { supplier }\end{array}$ & $X_{244}$ & $\min$ \\
\hline 2.4 .5 & $\begin{array}{l}\text { Ratio of the amount of imported coal to average } \\
\text { annual coal consumption }\end{array}$ & $X_{245}$ & $\min$ \\
\hline 2.5 & \multicolumn{3}{|l|}{ Nuclear fuel } \\
\hline 2.5 .1 & $\begin{array}{l}\text { Ratio of the amount of nuclear fuel purchased in the } \\
\text { nuclear fuel market to average annual nuclear fuel } \\
\text { consumption }\end{array}$ & $X_{251}$ & $\max$ \\
\hline 2.5 .2 & $\begin{array}{l}\text { Possibility for electricity producers to choose a nuclear } \\
\text { fuel supplier }\end{array}$ & $X_{252}$ & $\max$ \\
\hline 2.5 .3 & $\begin{array}{l}\text { Ratio of the purchase cost of nuclear fuel to average } \\
\text { open market cost }\end{array}$ & $X_{253}$ & $\min$ \\
\hline 2.5 .4 & $\begin{array}{l}\text { Share of the imported nuclear fuel from a single } \\
\text { possible supplier }\end{array}$ & $X_{254}$ & $\min$ \\
\hline 2.5 .5 & $\begin{array}{l}\text { Ratio of the imported nuclear fuel to average annual } \\
\text { nuclear fuel consumption }\end{array}$ & $X_{255}$ & $\min$ \\
\hline 2.6 & \multicolumn{3}{|l|}{ Biofuel } \\
\hline 2.6 .1 & $\begin{array}{l}\text { Ratio of the amount of biofuel purchased in the biofuel } \\
\text { market to average annual biofuel consumption }\end{array}$ & $X_{261}$ & $\max$ \\
\hline 2.6 .2 & Possibility for consumers to choose a biofuel supplier & $X_{262}$ & $\max$ \\
\hline 2.6 .3 & $\begin{array}{l}\text { Ratio of biofuel production cost to average open } \\
\text { market cost }\end{array}$ & $X_{263}$ & $\min$ \\
\hline 2.6 .4 & $\begin{array}{l}\text { Share of the imported biofuel from a single possible } \\
\text { supplier }\end{array}$ & $X_{264}$ & $\min$ \\
\hline 2.6 .5 & $\begin{array}{l}\text { Ratio of the amount of the imported biofuel to the total } \\
\text { amount of consumed biofuel }\end{array}$ & $X_{265}$ & $\min$ \\
\hline 2.7 & \multicolumn{3}{|l|}{ Heat } \\
\hline 2.7 .1 & Possibility for consumers to choose a heat supplier & $X_{271}$ & $\max$ \\
\hline 2.7 .2 & $\begin{array}{l}\text { Ratio of the production cost of heat (for } 1 \mathrm{kWh} \text { ) to } \\
\text { average production cost in the EU countries }\end{array}$ & $X_{272}$ & $\min$ \\
\hline
\end{tabular}


Table 1: $\quad$ Continued.

\begin{tabular}{|c|c|c|c|}
\hline $\mathrm{Nr}$ & Name of the indicator & Notation & $\begin{array}{l}\text { Direction } \\
\text { of the } \\
\text { scale }\end{array}$ \\
\hline 2.7 .3 & $\begin{array}{l}\text { Ratio of the amount of heat produced using fuel which } \\
\text { is possible to import from a single supplier to the total } \\
\text { amount of heat }\end{array}$ & $X_{273}$ & $\min$ \\
\hline 2.7 .4 & $\begin{array}{l}\text { Ratio of the amount of national fuel used for } \\
\text { production of heat to the total consumed amount of } \\
\text { fuel }\end{array}$ & $X_{274}$ & $\max$ \\
\hline 3 & \multicolumn{3}{|l|}{ Socio-political block } \\
\hline 3.1 & \multicolumn{3}{|l|}{ Geopolitics } \\
\hline 3.1 .1 & $\begin{array}{l}\text { The biggest share of the amount of energy resources } \\
\text { imported from a single country in the general energy } \\
\text { consumption balance }\end{array}$ & $X_{311}$ & $\min$ \\
\hline 3.1 .2 & $\begin{array}{l}\text { Weighted mean (according to the size of import) of } \\
\text { political risk factors of the countries, the energy } \\
\text { resources are imported from }\end{array}$ & $X_{312}$ & $\max$ \\
\hline 3.1 .3 & $\begin{array}{l}\text { Weighted mean (according to the size of transit) of } \\
\text { political risk factors of transit countries, the energy } \\
\text { resources are imported through }\end{array}$ & $X_{313}$ & $\max$ \\
\hline 3.1 .4 & $\begin{array}{l}\text { Weighted mean (according to the size of invested } \\
\text { capital) of political risk factors of foreign states that } \\
\text { have invested into national energy no less than } 10 \% \text { of } \\
\text { the energy system capital }\end{array}$ & $X_{314}$ & $\max$ \\
\hline 3.1 .5 & Political risk factor of the country & $X_{315}$ & $\max$ \\
\hline 3.2 & \multicolumn{3}{|l|}{ Socio-politics } \\
\hline 3.2 .1 & $\begin{array}{l}\text { Average expenses for energy per inhabitant in } \\
\text { comparison with average annual income }\end{array}$ & $X_{321}$ & $\min$ \\
\hline 3.2 .2 & $\begin{array}{l}\text { Degree of undertaking the commitment regarding the } \\
\text { share of renewable energy in the total final } \\
\text { consumption }\end{array}$ & $X_{322}$ & $\max$ \\
\hline 3.2 .3 & $\begin{array}{l}\text { Degree of following the requirements of Kyoto } \\
\text { Protocol regarding the reduction of greenhouse gas } \\
\text { emission }\end{array}$ & $X_{323}$ & $\max$ \\
\hline 3.2 .4 & $\begin{array}{l}\text { Degree of undertaking the commitment regarding } \\
\text { energy saving }\end{array}$ & $X_{324}$ & $\max$ \\
\hline 3.2 .5 & $\begin{array}{l}\text { Positive social assessment of the development of } \\
\text { nuclear power in the country }\end{array}$ & $X_{325}$ & $\max$ \\
\hline
\end{tabular}

of the evaluation scale; thus, the values increase when $p c t v_{i j k}>c t v_{i j k}$ (e.g. the indicator $X_{111}$ "Ratio of total installed power capacity of generators and connections lines to the maximal power demand") and decrease when pctv $_{i j k}<c t v_{i j k}$ (e.g. the indicator $X_{112}$ "Ratio of the largest power plant capacity to installed capacity of the whole system"). In the first case, the higher value of the 
indicator corresponds to the higher level of security, whereas in the second case to the lower. Pre-critical and critical threshold values were employed for dividing the increasing and decreasing scales of factual values of the indicators into three following parts: normal, pre-critical and critical states which were further subdivided into five equal parts accordingly. After that, each state was evaluated by points from 1 to 15 : normal state - 11-15 points; pre-critical state 6-10 points; critical state $-1-5$ points. In our previous works $[4,5]$ or in the works of other scientists $[6,7]$, an 8 -point indicator evaluation scale (8 points normal state, 7-5 points - pre-critical state and 4-1 points - critical state) is used, but we noticed that this scale lacks sensitivity.

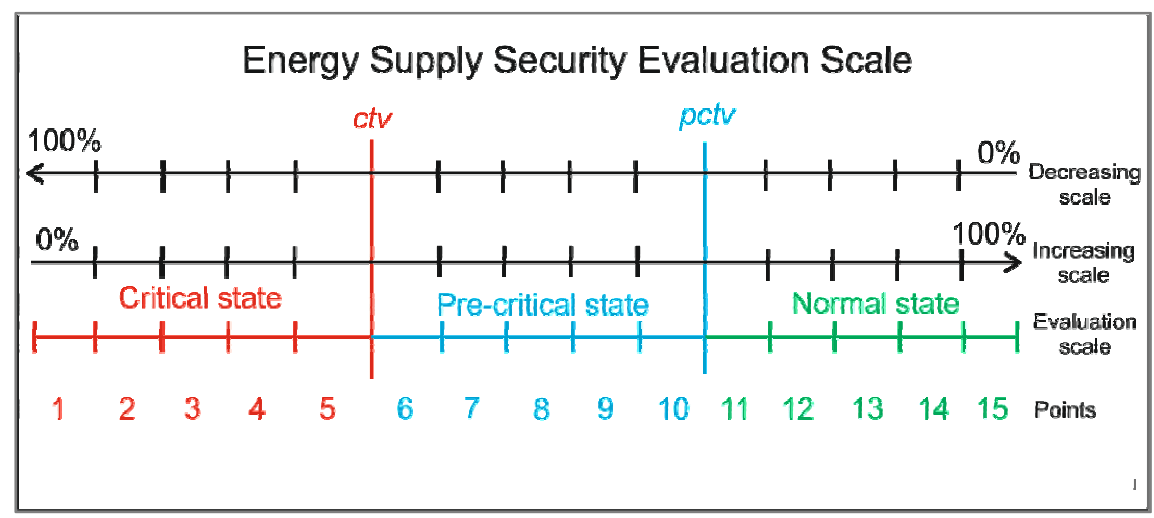

Figure 1: $\quad$ Scale of energy supply security state assessment.

Each indicator of the research year was evaluated by points from 1 to 15 and defined as $X_{i j k}^{p}$ taking into consideration the factual value of each indicator. When the direction of the indicator scale is decreasing, the state of the indicator is considered as:

- $\quad$ normal when indicator value is $X_{i j k}<p c t v_{i j k}$;

- $\quad$ pre-critical when $p c t v_{i j k} \leq X_{i j k} \leq c t v_{i j k}$;

- $\quad$ critical when $X_{i j k}>c t v_{i j k}$.

When the direction of the indicator scale is increasing the state is:

- $\quad$ normal when the indicator's value is $X_{i j k}>p c t v_{i j k}$;

- $\quad$ pre-critical when $c t v_{i j k} \leq X_{i j k} \leq p c t v_{i j k}$;

- $\quad$ critical when $X_{i j k}<c t v_{i j k}$.

It is necessary to establish the weights of indicators in each group on purpose to assess the level of security of energy supply. In our previous papers we used equal indicator weights or weights evaluated by expert assessment method $[4,5]$. As the indicators are interdependent in each group, between groups and blocks, it is advisable to calculate indicator weights considering the correlation coefficients between the indicators. Correlation coefficients were calculated using statistical data, i.e. evoking factual values of indicators. In this paper, we made an assumption that indicators are interdependent only inside the group. Considering 
the correlation coefficients, dependencies between the indicators can be described by the following equation (1):

$$
X_{i j k}=1+\sum_{\substack{t=1 \\ t \neq k}}^{l} r_{k t} X_{i j t}, \quad i=1, \ldots, n, j=1, \ldots, m, k=1, \ldots, l,
$$

here $r_{k t}$ - correlation coefficient between indicators $t$ and $k$. Using equation (1) a symmetric correlation matrix can be written as follows:

$$
\mathrm{R}_{i j}=\left(\begin{array}{cccc}
1 & r_{12} & \ldots & r_{1 l} \\
r_{21} & 1 & \ldots & r_{2 l} \\
\ldots & \ldots & \ldots & \ldots \\
r_{l 1} & r_{l 2} & \ldots & 1
\end{array}\right), i=1, \ldots, n, j=1, \ldots, m .
$$

The indicators which are independent from other indicators in the group have the biggest weight. The dependent indicators have less weight as they influence the level of security of energy supply through their correlations. Using the correlation matrix (2) auxiliary coefficients were calculated in such manner:

$$
\alpha_{k}=\sum_{t=1}^{l}\left(1-\left|r_{k t}\right|\right), \quad k=1, \ldots, l,
$$

and vector $\alpha=\left(\alpha_{1}, \alpha_{2}, \ldots, \alpha_{l}\right)$ was constructed. Next, each indicator weight in the group can be calculated according to the following formula:

$$
s_{i j k}=\frac{\alpha_{k}}{\|\alpha\|_{\Sigma}}, i=1, \ldots, n, j=1, \ldots, m, k=1, \ldots, l,
$$

here $\|\alpha\|_{\Sigma}=\sum_{i=1}^{n}\left|\alpha_{i}\right|$. Coefficients $s_{i j k}$ obtain values in the interval

$$
\frac{1}{\|\alpha\|_{\Sigma}} \leq s_{i j k} \leq \frac{l}{\|\alpha\|_{\Sigma}}
$$

i.e. the maximum weight of indicator in the group is 0.5 .

The state of security of energy supply was evaluated taking into account the weights of blocks $s_{i}$, groups $s_{i j}$ and indicators $s_{i j k}$ according to the formula:

$$
B=\sum_{i=1}^{n}\left(s_{i} \sum_{j=1}^{m}\left(s_{i j} \sum_{k=1}^{l} s_{i j k} X_{i j k}^{p}\right)\right) \text {. }
$$

\section{Assessment of level of security of energy supply in Lithuania}

Taking into consideration the assessment of indicators in points, their weights in groups, and weights of groups and blocks, the security of energy supply in Lithuania of separate indicator blocks was determined (on 15-point scale) at first. The results are presented in table 2 .

The integral characteristics of security of energy supply in Lithuania in the years 2007, 2010 and after building the LNG terminal are presented in fig. 2. The level of security of energy supply is in pre-critical state, but building the LNG terminal would increase energy security level by 1.3 points. 
Table 2: Assessment of technical, economic and socio-political blocks in points.

\begin{tabular}{|l|c|c|c|}
\hline \multicolumn{1}{|r|}{ Year } & 2007 & 2010 & \multirow{2}{*}{ LNG terminal } \\
\cline { 1 - 3 } Block & 8.82 & 7.61 & 9.21 \\
\hline Technical & 6.26 & 5.51 & 7.70 \\
\hline Economic & 6.59 & 6.64 & 6.75 \\
\hline Socio-political & &
\end{tabular}

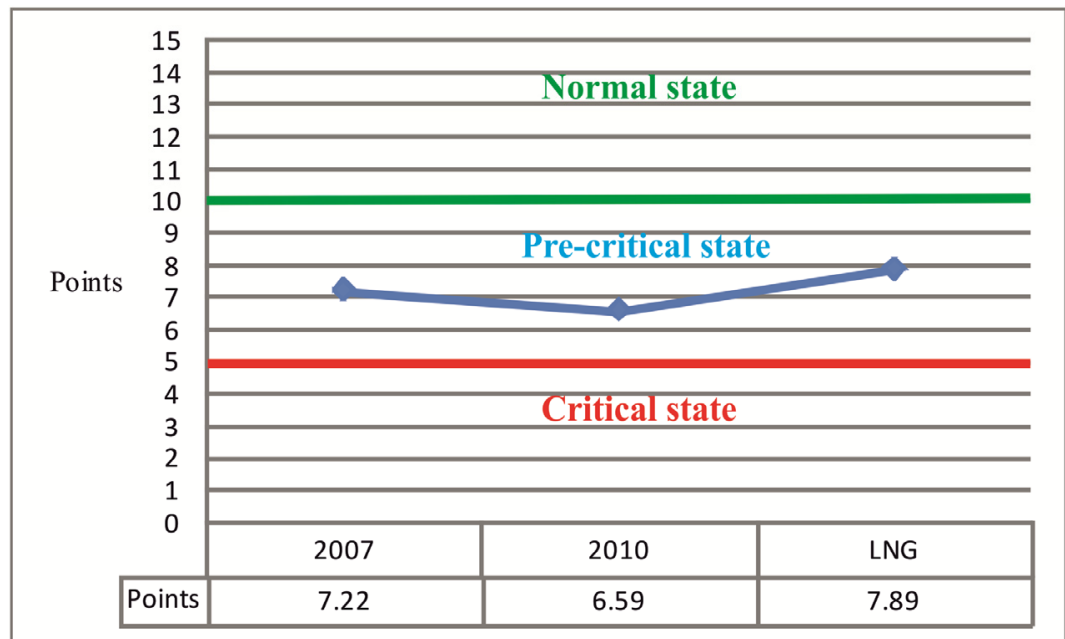

Figure 2: $\quad$ State of security of energy supply in Lithuania in 2007, 2010 and after building the LNG terminal.

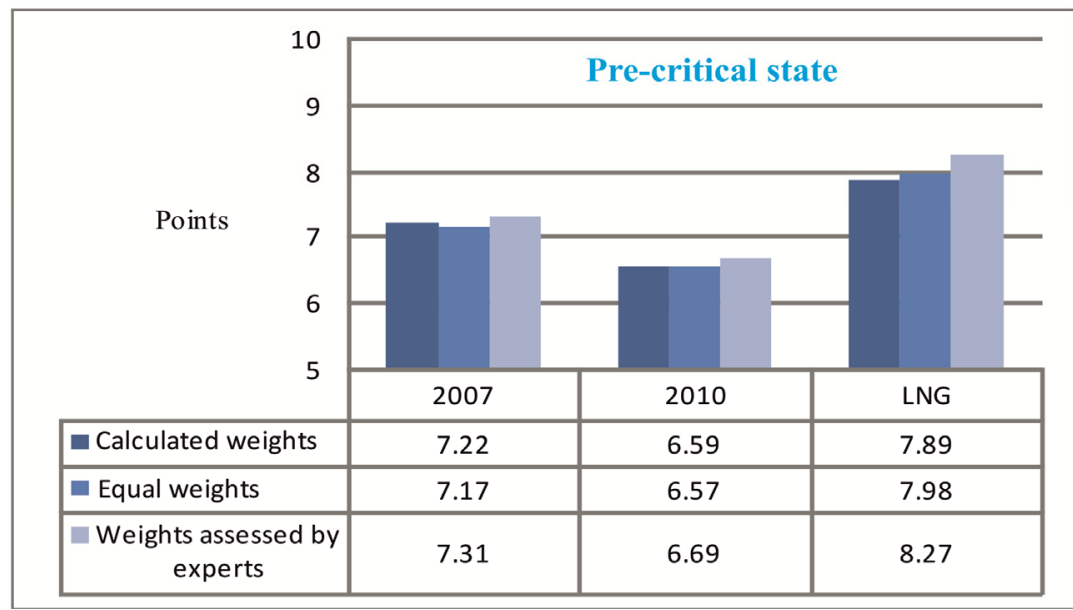

Figure 3: State of Lithuanian energy supply security estimated different weights of indicators in groups. 
For the sake of comparison we calculated the level of security of Lithuanian energy supply using two different types of indicator weights, i.e. equal weights and weights determined by experts. The results are presented in fig. 3 .

\section{Conclusions}

1. Each intended object in the energy development programme (such as LNG terminal, electricity network between Lithuania and Sweden NORDBALT, etc.) influence the changes of certain values of indicators in all three blocks: the values of some indicators increase and some values decrease.

2. The state of security of energy supply in Lithuania will increase up to 7.89 and 7.98 points (calculated or equal weights of indicators in groups) or up to 8.27 points (weights of indicators assessed by experts) after building the LNG terminal.

3. When the weights of indicators in groups are calculated on the basis of correlations, then the level of security of energy supply in Lithuania is pre-critical.

\section{Acknowledgement}

This research was funded by a grant (No. ATE-08/2010) from the Research Council of Lithuania.

\section{References}

[1] National Energy Strategy. Certified by resolution of LR parliament No. X1046, January 18, 2007.

[2] National Energy (Energy Independence) Strategy. Government of the Republic of Lithuania endorsed the National Energy (Energy Independence) Strategy by Resolution No. 1426 on October 6, 2010.

[3] International Country Risk Guide, Copyright. 1984-Present. The PRS Group, Inc. Available from Internet: <www.prsgroup.com>.

[4] Augutis, J., Krikštolaitis, R., Pečiulytė, S., Konstantinavičiūtè, I. Sustainable development and energy security level after Ignalina NPP shutdown. Technological and Economic Development of Economy, 17(1), 2011. p. 5-21.

[5] Augutis, J., Krikštolaitis, R., Matuzienè, V., Pečiulytė, S. Assessment of Lithuanian power supply security depending on nuclear energy // Safety and security engineering III : third international conference on safety and security engineering, Rome, Italy, July 1-3, 2009. p. 235-247.

[6] Bykova, E. V. The methods of calculation and the analysis of indexes of energy security // Monograph, 2005. (Bykova E. V. Metody rascheta i analiz pokazatelei energeticheskoi bezopasnosti. Kishinev, 2005. (in Russian).) 
82 Safety and Security Engineering IV

[7] Mixalevich, A. A., Bykova, E. V., Postolatii, V. M., Fisenko, S. P., Shnip, A. I., Rimko, D. V., Grodeckii, M. V. Metodicheskie podxody k resheniju problemy energeticheskoi bezopasnosti Moldovy i Belarusi // Monograph, 2010. (in Russian) 